\title{
Does COVID-19 Involve the Retina?
}

\author{
Michael Karampelas (1) $\cdot$ Maria Dalamaga $\cdot$ Irene Karampela
}

Received: August 18, 2020 / Accepted: September 3, 2020 / Published online: September 21, 2020

(C) The Author(s) 2020

\begin{abstract}
Endothelial cell involvement with COVID-19 has been shown in the lung, heart, kidney, intestine and brain with histopathological evidence of endotheliitis and vasculitis. Viral RNA of COVID-19 has been detected in the retina of affected patients and recent publications highlight the possibility of retinal microangiopathy in patients with confirmed COVID-19 infection. Given the magnitude of the current pandemic, emphasis should be given to better reporting of clinically significant ocular symptoms, e.g. new scotoma, which could indicate the need for a retinal examination as well as follow-up testing after recovery from COVID19.
\end{abstract}

Digital Features To view digital features for this article go to https://doi.org/10.6084/m9.figshare.12907244.

M. Karampelas (ه)

Medical Retina Department, Hippokration General Hospital, Athens, Greece

e-mail: mikekarampelas@hotmail.com

\section{Dalamaga}

Department of Biological Chemistry, Medical School, National and Kapodistrian University of Athens, Athens, Greece

I. Karampela

Second Department of Critical Care, Attikon General University Hospital, Medical School, National and Kapodistrian University of Athens, Chaidari, Greece
Keywords: COVID-19; Microangiopathy; Retina; SARS-CoV-2

\section{Key Summary Points}

Endothelial cell involvement with COVID-19 has been shown in the lung, heart, kidney, intestine and brain.

Viral RNA of COVID-19 has been detected in the retina of affected patients.

Recent publications provide evidence of retinal microangiopathy in patients with confirmed COVID-19 infection.

Emphasis should be given to better reporting of clinically significant ocular symptoms, e.g. new scotoma, which could indicate the need for a retinal examination as well as follow-up testing after recovery from COVID-19.

\section{DIGITAL FEATURES}

This article is published with digital features to facilitate understanding of the article. To view digital features for this article go to https://doi. org/10.6084/m9.figshare.12907244. 
Recently, Marinho et al. reported optical coherence tomography (OCT) findings from 12 patients with confirmed COVID-19 infection [1]. All cases demonstrated focal hyper-reflective areas located in the inner retina and four cases also exhibited subtle cotton wool spots and retinal microhaemorrhages. Subsequently, Vavvas et al. highlighted the fact that the observed hyper-reflective areas on OCT could possibly represent normal retinal vessels while the presence of subtle cotton wool spots might be related to some other pathologic process or alternatively represent a discrete area of myelinated nerve fibres [2]. It was also pointed out that the absence of near-infrared reflectance imaging, OCT angiography abnormalities as well as follow-up scans should be taken into account while interpreting these findings. Furthermore, Virgo and Mohamed presented two patients with paracentral acute middle maculopathy and acute macular neuroretinopathy following SARS-CoV-2 infection [3] and Landecho et al. evaluated 27 asymptomatic subjects with previous COVID-19 respiratory tract infection and found that six of them had cotton wool spots [4]. In addition, Insausti-García et al. reported a case of papillophlebitis associated with SARS-CoV-2 [5].

COVID-19 infects the host using the angiotensin-converting enzyme 2 receptor, which is expressed in several organs including retinal endothelial cells [6]. Endothelial cell involvement with COVID-19 has been shown in the lung, heart, kidney, intestine and brain and histopathological studies have demonstrated direct viral infection of endothelial cells, endotheliitis and vasculitis in both arterial and venous circulations [7, 8]. Inflammation of endothelial cells induces oedema, congestion and thrombosis of small vessels, which eventually result in organ ischemia. These findings suggest that COVID-19 is a systemic disease involving multiple organs through direct viral invasion as well as immune-mediated inflammation, and inducing a widespread endotheliitis which may cause microvascular dysfunction and tissue ischemia. Furthermore, viral RNA of COVID-19 has been detected in the retina of affected patients [9]. This finding raises the hypothesis that COVID-19 may cause retinal vasculitis and ischemia.

Acute retinal ischemia is known to be associated with inner retina hyper-reflectivity on OCT and discrete hyper-reflective areas in the inner retina have been linked with superficial capillary ischemia [10]. Viral infection is a rare cause of retinitis but relevant cases have been previously reported. Occlusive retinal vasculitis has been described in eight cases of infection with West Nile virus and in one case with coxsackievirus A4 [11, 12]. In the latter report, focal hyper-reflective regions in the inner retina were present on OCT.

The above evidence suggests that retinal involvement by COVID-19 is certainly plausible. This possibility is of particular importance in patients at high risk for retinopathy, such as patients with diabetes and hypertension. Of note, diabetes and hypertension have been shown to be among the most prominent risk factors for COVID-19. Therefore, prospective studies of patients with COVID-19 and a previously diagnosed retinopathy could be particularly useful regarding the clinical importance and possible implications. Given the magnitude of the current pandemic as well as the great challenges in terms of diagnosis and management, we should give emphasis to better reporting of clinically significant ocular symptoms, e.g. new scotoma, which could indicate the need for a retinal examination as well as follow-up testing after recovery from COVID19 , in order to further explore the possibility of retinal involvement.

\section{ACKNOWLEDGEMENTS}

Funding. No funding or sponsorship was received for this study or publication of this article.

Authorship. All named authors meet the International Committee of Medical Journal Editors (ICMJE) criteria for authorship for this article, take responsibility for the integrity of the work as a whole, and have given their approval for this version to be published. 
Disclosures. Michael Karampelas is a member of the journal's Editorial Board. Maria Dalamaga and Irene Karampela have nothing to declare.

Compliance with Ethics Guidelines. This article is based on previously conducted studies and does not contain any studies with human participants or animals performed by any of the authors.

Open Access. This article is licensed under a Creative Commons Attribution-NonCommercial 4.0 International License, which permits any non-commercial use, sharing, adaptation, distribution and reproduction in any medium or format, as long as you give appropriate credit to the original author(s) and the source, provide a link to the Creative Commons licence, and indicate if changes were made. The images or other third party material in this article are included in the article's Creative Commons licence, unless indicated otherwise in a credit line to the material. If material is not included in the article's Creative Commons licence and your intended use is not permitted by statutory regulation or exceeds the permitted use, you will need to obtain permission directly from the copyright holder. To view a copy of this licence, visit http://creativecommons.org/licenses/by$\mathrm{nc} / 4.0 /$.

\section{REFERENCES}

1. Marinho PM, Marcos AAA, Romano AC, Nascimento $\mathrm{H}$, Belfort R. Retinal findings in patients with COVID-19. Lancet. 2020. https://doi.org/10. 1016/S0140-6736(20)31014-X.

2. Vavvas DG, Sarraf D, Sadda SR, et al. Concerns about the interpretation of OCT and fundus findings in COVID-19 patients in recent Lancet publication. Eye (Lond). 2020;9:1-2.

3. Virgo J, Mohamed M. Paracentral acute middle maculopathy and acute macular neuroretinopathy following SARS-CoV-2 infection. Eye. 2020. https:// doi.org/10.1038/s41433-020-1069-8.

4. Landecho MF, Yuste JR, Gándara E, et al. COVID-19 retinal microangiopathy as an in vivo biomarker of systemic vascular disease? J Intern Med. 2020. https://doi.org/10.1111/joim.13156.

5. Insausti-García A, Reche-Sainz JA, Ruiz-Arranz C, López Vázquez Á, Ferro-Osuna M. Papillophlebitis in a COVID-19 patient: inflammation and hypercoagulable state. Eur J Ophthalmol. 2020. https:// doi.org/10.1177/1120672120947591.

6. Senanayake P, Drazba J, Shadrach K, et al. Angiotensin II and its receptor subtypes in the human retina. Invest Ophthalmol Vis Sci. 2007;48(7): 3301-11.

7. Varga Z, Flammer AJ, Steiger P, et al. Endothelial cell infection and endotheliitis in COVID-19. Lancet. 2020;395:1417-8.

8. Hanafi R, Roger PA, Perin B, et al. COVID-19 neurologic complication with CNS vasculitis-like pattern. AJNR Am J Neuroradiol. 2020. https://doi.org/ 10.3174/ajnr.A6651.

9. Casagrande M, Fitzek A, Püschel K, et al. Detection of SARS-CoV-2 in human retinal biopsies of deceased COVID-19 patients. Ocul Immunol Inflamm. 2020;28:721-5. https://doi.org/10.1080/ 09273948.2020 .1770301 .

10. Yu S, Pang CE, Gong Y, et al. The spectrum of superficial and deep capillary ischemia in retinal artery occlusion. Am J Ophthalmol. 2015;159(1): 53-6312.

11. Talat L, Lightman S, Tomkins-Netzer O. Ischemic retinal vasculitis and its management. J Ophthalmol. 2014;2014:197675.

12. Mine I, Taguchi M, Sakurai Y, Takeuchi M. Bilateral idiopathic retinal vasculitis following coxsackievirus A4 infection: a case report. BMC Ophthalmol. 2017;17(1):128. 